\title{
Risk/benefit considerations of a new formulation of wheat-based biscuit supplemented with different amounts of chia flour
}

\author{
M. Mesías, F. Holgado, G. Márquez-Ruiz, F.J. Morales \\ Institute of Food Science, Technology and Nutrition, ICTAN-CSIC, Madrid 28040, Spain
}

\begin{abstract}
The incorporation of Chia (Salvia hispanica L.) in the formulation of certain foods may be particularly desirable from a nutritional and healthy point of view. The effect of addition of chia flour on the nutritional properties and the formation of process contaminants in wheat flour-based biscuits was investigated. Higher percentage of chia flour in the formula increased the antioxidant capacity, phenolic compounds, protein, fiber and polyunsaturated fatty acids content, then resulting in a nutritionally enhanced product. However levels of process contaminants were also increased and thus acrylamide, hydroxymethylfurfural and furfural ranged between $15 \mathrm{I}$ and $1188 \mathrm{mg} / \mathrm{kg}, 22.8-71.4 \mathrm{mg} / \mathrm{kg}$ and $1.3-5.6 \mathrm{mg} / \mathrm{kg}$, respectively, when chia was added in a range of $0-20 \%$ of the total weight. In parallel, the formation of dicarbonyl compounds, such as methylglyoxal and glyoxal, were significantly increased with addition of $5 \%$. Lipid oxidation, particularly polymerization compounds, was accelerated in chia enriched biscuits, which decreased the shelf-life of the product by promoting a rapid rancidity under accelerated storage conditions. Therefore, although nutritional properties are improved by the incorporation of chia into the biscuits, the increase in the content of process contaminants and the extent of the lipid oxidation should be carefully considered in a context of risk/benefit.
\end{abstract}

KEYWORDS: Biscuits, chia flour, acrylamide, furfurals, lipid oxidation

\section{INTRODUCTION}

In the last decades the search for functional foods has been widely pursued by food companies. Consumers demand new food products not only to satisfy a physiological need but also to obtain necessary nutrients to prevent nutrition-related diseases and to improve physical and mental health. In this regard, a close link between nutrition and health has been established and functional foods containing ingredients with a specific health benefit are being developed technologically (Niva, 2007).

Chia (Salvia hispanica L.) is an oilseed plant used as foodstuff due to being a natural source of many nutrients. Chia seed contains significant amount of protein, fiber, vitamins, minerals and other constituents including phytoestrogens and antioxidants, such as tocopherols and phenolic compounds. In addition, chia seed stands out because of its high content of polyunsaturated fatty acids (PUFA), especially a-linolenic acid. Due to its nutritional value and chemical composition, different medicinal properties have been attributed to the chia seed and it has been considered as a new functional ingredient (Reyes-Caudillo, Tecante, \& Valdivia-López, 2008). Therefore, its incorporation in the formulation of certain foods may be particularly desirable from a nutritional and healthy point of view.

Following the specifications of the European Commission (EC), chia seed has been approved to be used as a novel food ingredient in baked products but in amounts no more than $10 \%$, since there are uncertainties with respect to its potential allergenicity (EC, 2013). However, changes in the formulation may affect, in addition to the rheological, technological and sensory parameters, the formation of process contaminants, such as acrylamide, hydroxymethylfurfural (HMF) or furfural when foods are thermally treated. Basically,

M. Mesías, F. Holgado, G. Márquez-Ruiz, F.J. Morales / LWT Food Science and Technology 73 (2016) $528-535$ pag. I 
these contaminants are produced by the Maillard reaction initiated by carbohydrates but also by carbonyls generated from the lipid oxidation (Zamora \& Hidalgo, 20l I). Acrylamide is generated as the result of the reaction between asparagine and reducing sugars as the main precursors. Recently, the European Food Safety Agency has confirmed that the presence of acrylamide in food is a public health concern, requiring continued efforts to reduce its exposure (EFSA, 20I5). HMF and furfural are formed as intermediate products of the Maillard reaction and furthermore, HMF is also generated by the caramelization of sugars at high temperature (Morales, 2008). Based on studies in animals, HMF is suspected to have potential genotoxic and mutagenic effects through its metabolism product sulphoxymethylfurfural (Høie et al., 20I5) whereas furfural may lead to hepatotoxicity (EFSA, 2005).

The purpose of this study was to investigate the effect of incorporating different amounts of chia flour in wheat-based biscuits on the nutritional properties, antioxidant content and the formation of acrylamide, HMF and furfural, assessing the risk/benefit of these new formulations. The oxidative stability in the biscuits after storage was also evaluated.

\section{MATERIALS AND METHODS}

\section{Reagents and Chemicals}

Chia flour was supplied by Harinas Polo (Zaragoza, Spain). Hard wheat flour (I2.2\% protein) and other foodgrade ingredients were purchased from local supermarkets. HPLC-grade methanol was from Merck (Darmstadt, Germany). All chemicals used were obtained from Sigma Aldrich (St. Louis, MO, USA). All chemicals, solvents and reagents were of analytical grade.

\section{Preparation of biscuits}

Both control and chia-enriched biscuits were prepared according to a recipe described in AACC (American Association of Cereal Chemists) method 10-54 (AACC, 2000) following the procedure described by Mesías, Holgado, Márquez-Ruiz and Morales (2015a). Control biscuit was formulated with wheat flour (130 g), sucrose (35 g), distilled water (30 g), sunflower oil ( $26 \mathrm{~g})$, sodium bicarbonate $(0.8 \mathrm{~g})$, ammonium bicarbonate $(0.4 \mathrm{~g})$ and salt $(\mathrm{lg})$. Four different biscuits were formulated replacing wheat flour by chia flour so as to achieve percentages of chia in the final weight of $5 \%$ (sample A), $10 \%$ (sample B), $15 \%$ (sample C) and $20 \%$ (sample D). The final amount of solids in the dough remained the same. The ingredients were thoroughly mixed and the dough was rolled out to disks with the diameter of $6 \mathrm{~cm}$ and the thickness of 2 $\mathrm{mm}$, and baked at $190^{\circ} \mathrm{C}$ for $20 \mathrm{~min}$ in a conventional oven (Memmert UNE 400, Germany). Twelve biscuits per batch and two batches per formulation were prepared. Three biscuits per batch were grinded and mixed and analytical determinations were performed in duplicate for each mixture, thereby obtaining two different values from the two batches corresponding to six different biscuits per formulation. For the determination of hardness two biscuits per batch for each formulation were used. For the storage assay, nine biscuits per formulation were randomly selected and three of the biscuits were taken after 30,60 and 90 days.

\section{Determination of moisture and water activity (Aw)}

Moisture was determined gravimetrically to constant weight in an oven at $105^{\circ} \mathrm{C}$ for $24 \mathrm{~h}$ according to the AOAC (1999) method. The water activity of biscuits was measured at $25^{\circ} \mathrm{C}$ by an AquaLAB CX-2 (Decagon Devices Inc., Pullman, WA).

\section{Measurement of pH}


Biscuits ( $1 \mathrm{~g}$ ) were mixed with $100 \mathrm{~mL}$ of water and vortexed for $3 \mathrm{~min}$. The mixture was held at room temperature for $\mathrm{I} \mathrm{h}$ and centrifuged to separate phases. $\mathrm{pH}$ of the supernatant was measured using a CG$837 \mathrm{pH}$ meter (Schott, Mainz, Germany).

\section{Determination of colour}

The measurements were made using a HunterLab Spectrophotometer CM-3500D colorimeter (Hunter Associates laboratory, Stamford, Connecticut, USA). Three independent measurements of a*(redness), $b *$ (yellowness) and $L *$ (lightness) parameters were carried out on different areas of the biscuit samples. $E$ index was calculated according to the following equation: $E=\left(L^{2}+a^{2}+b^{2}\right)^{1 / 2}$ (Morales \& Jiménez-Pérez, 200I).

\section{Determination of hardness}

The hardness of the biscuits was evaluated using the Texture Analyzer TA-TXPlus (Texture Technologies Corporation, USA) equipped with a $50 \mathrm{~kg}$ load cell, a probe (Warner-Bratzcer, HDP/BSK knife model) with a compression speed at $1 \mathrm{~mm} / \mathrm{s}$ and a distance prolongation of $10 \mathrm{~mm}$. The force at the first major drop in the force-deformation curve (Fmax) and deformation at maximum force were obtained for 4 replicates per sample. The results of hardness were expressed as $\mathrm{N}$ (Newton).

\section{Determination of water retention capacity}

Flours $(5 \mathrm{~g}$ ) were placed in a pre-weighed centrifuge tube to which $30 \mathrm{~mL}$ ofwaterwas added. The mixture was vortex for I min, held at room temperature for $30 \mathrm{~min}$ and centrifuged at $1400 \mathrm{~g}$ for $15 \mathrm{~min}$. The nonabsorbed water was discharged and the tube was weighed. Water retention capacity was calculated by the following formula: [(weight of tube with sample and water retained - weight of tube with sample)/(weight of water added $)] \times 100$.

\section{Determination of total protein content}

Total protein content was determined using an automated nitrogen analyzer (FP-2000; Dumas Leco Corp., St. Joseph, MI). The nitrogen-to-protein conversion factor was $N \times 5.7$ according to the AOAC (1999) indications. The results were expressed as g protein/l00 g sample.

\section{Determination of total fat content by Soxhlet extraction}

Total fat content was determined by Soxhlet extraction (Soxtec System HT6, Tecator AB, H€ogan€as, Sweden), according to the AOAC (1999) method using petroleum ether. The results were expressed as $g$ lipid/l $00 \mathrm{~g}$ sample.

\section{Determination of carbohydrates}

The total carbohydrate content was determined using the method described by Dubois, Gilles, Hamilton, Rebers, and Smith (1956). A calibration plot was drawn using a standard glucose solution in the range of $0.25 \mathrm{e} 2.0 \mathrm{mg} / \mathrm{mL}$. Results were expressed as g glucose equivalents $/ \mathrm{l} 00 \mathrm{~g}$ sample.

\section{Determination of reducing sugars}

The reducing sugars content was determined by Miller (1959) in the range of $0.25-2.0 \mathrm{mg} / \mathrm{mL}$. Results were expressed as g glucose equivalents/l $00 \mathrm{~g}$ sample.

\section{Determination of total dietary fiber}


Total dietary fiber was determined by an enzymatic-gravimetric method based on the AOAC methods 991.43 and 985.29 (Lee, Prosky, \& De Vries, 1992; Prosky, Asp, Schweizer, Devries, \& Furda, 1992) and employing the Total Dietary Fiber Assay Kit (Megazyme International Ireland, Ireland). Results were expressed as $\mathrm{g}$ fiber/l $100 \mathrm{~g}$ sample.

\section{Determination of free asparagine}

Free asparagine was extracted from the flours with $\mathrm{HCl} 0.1 \mathrm{~N}$. Derivatization by using of phenyl isothiocyanate (PITC) and HPLC quantification was carried out following the method of Martínez-Villaluenga, Gulewicz, Frias, Gulewicz, and Vidal-Valverde (2008). Norleucine was used as internal standard. Results were expressed as $\mathrm{mg} / \mathrm{l} 00 \mathrm{~g}$ sample.

\section{Determination of phenolic acids}

Phenolic acids ( $\mathrm{p}$-hydroxybenzoic acid, syringic acid, vanillic acid, $\mathrm{p}$-coumaric acid, caffeic acid, ferulic acid, protocatechuic acid and chlorogenic acid) were determined chromatographically according to the method described by Mesías, Navarro, Gökmen, and Morales (20l3). Results were expressed as mg/g sample.

\section{Determination of total phenolic content}

Total phenolic content (TPC) was determined by the Foline Ciocalteu method. A direct measurement of the samples without extraction prior analysis was according to Horszwald, Morales, del Castillo, and Zielinski (2010). Results were expressed as mg gallic acid equivalents (GAE)/g sample.

\section{Total antioxidant capacity by direct $\mathrm{ABTS}^{+}$assay}

The direct measurement of the total antioxidant capacity was performed according to G€okmen, Serpen, and Fogliano (2009) and adapted to microplate reader. Trolox was used for the calibration and results were expressed as mmol equivalents of trolox (TEAC)/g sample.

\section{Total antioxidant capacity by DPPH}

DPPH (2,2,diphenyl-I-picrylhydrazyl hydrate) radical scavenging activity was determined as described by Morales, Martin, Açar, Arribas-Lorenzo, and G€okmen (2009). Results were expressed as mmol TEAC/g sample.

Total antioxidant capacity by the oxygen radical absorbance capacity (ORAC)

ROO- scavenging activity was measured as described in Morales et al. (2009). Results were expressed as mmol TEAC/g sample.

\section{Ferric reducing capacity by FRAP}

Ferric reducing antioxidant power (FRAP) was determined as described by Morales et al. (2009). Results were expressed as mmol TEAC/g sample.

\section{Determination of HMF and furfural}

HMF and furfural were determined following the HPLC method described by Mesías et al. (2015a). The limit of quantification was set at $0.6 \mathrm{mg} / \mathrm{kg}$ and $0.3 \mathrm{mg} / \mathrm{kg}$ for $\mathrm{HMF}$ and furfural, respectively. Results were expressed as $\mathrm{mg} / \mathrm{kg}$ sample.

\section{LC-ESI-MS-MS determination of acrylamide}


Acrylamide was determined as described by Mesías et al. (2015a). The limit of the quantitation was set at 16 $\mathrm{mg} / \mathrm{kg}$. The accuracy of the results were recently demonstrated for crispbread in an interlaboratory comparison study (report 3056, july 2015) launched by Food Analysis Performance Assessment Scheme (FAPAS) program (2015), yielding a z-score of 0.3 . Results were expressed as $\mathrm{mg} / \mathrm{kg}$ sample.

\section{Determination of dicarbonyl compounds}

Glyoxal (GO) and methylglyoxal (MGO) were determined according to the method of Arribas-Lorenzo and Morales (2010). Results were expressed as $\mathrm{mg} / \mathrm{g}$ sample.

\section{Storage of biscuits}

Biscuits were stored at $37^{\circ} \mathrm{C}$ in the dark without oxygen restriction, at atmospheric pressure, in order to evaluate oxidative stability (García-Martínez et al., 20l0). Three biscuits were taken after 30,60 and 90 days. 2.24. Extraction and determination of fatty acids profile Lipid fraction was extracted from both initial and stored biscuits with chloroform/methanol. The determination of fatty acids profile in the extracted lipids was conducted by analysis of fatty acid methyl esters (FAME). Results were expressed as relative percentages. FAME were prepared by base-catalysed transmethylation of the extracted lipids using $2 \mathrm{M} \mathrm{KOH}$ in methanol as described by IUPAC (1992a, 1992b) and analysed according to Mesías et al. (2015b).

\section{Determination of peroxide value}

Peroxide value was determined in lipids extracted from initial and stored biscuits by the iodometric assay following IUPAC standard method 2.50I (IUPAC, 1992c). Results were expressed as meq $\mathrm{O}_{2} / \mathrm{kg}$ oil.

\section{Determination of polymeric and hydrolytic compounds}

Aliquots of $50 \mathrm{mg}$ lipids extracted from initial and stored biscuits were dissolved in $\mathrm{I} \mathrm{mL}$ tetrahydrofuran for direct analysis by high performance size-exclusion chromatography (HPSEC) following the procedure of Márquez-Ruiz and Dobarganes (2007). The groups of oxidation compounds quantified were triacylglycerol dimers and higher oligomers. The sum of dimers and higher oligomers will be referred to as total polymers. Hydrolytic compounds (diglycerides and free fatty acids) were also quantified in the same analysis. Results were expressed as weight percentage on lipids.

\section{Statistical analysis}

Statistical analyses were performed using Statgraphics Centurion XV (Herndon, VA, USA). Data were expressed as mean \pm standard deviation (SD). Analysis of variance (ANOVA) and the least significant difference (LSD) test were applied to determine differences between means. Differences were considered to be significant at $p<0.05$. Relationships between the different parameters analysed were evaluated by computing Pearson linear correlation coefficients at the $p<0.05$ confidence level.

\section{RESULTS AND DISCUSSION}

Five formulations of biscuits were prepared maintaining the same recipe except for the content and type of flour added. Wheat flour in the control recipe was gradually replaced with chia flour in a range between 5 and $20 \%$ of the final weight, thus accounting for $9 \%, 17 \%, 26 \%$ and $34 \%$ of the total flour added to the biscuits A, B, C and D, respectively. According to the European Commission, chia seed is allowed to be used as an ingredient in baked products at levels lower than $10 \%$ (EC, 20I3), however percentages up to $20 \%$ were tested in order to get more insight on the formation of process contaminants during baking process as well as on the lipid oxidation after storage. 
In a first step, the reproducibility of the baking process was evaluated on the different batches of a same formulation. Colour index, HMF and acrylamide were determined in each batch obtaining relative standard deviations (RSD) of $0.5-6.7 \%$ for $\mathrm{a}^{*}, 1.3-3.8 \%$ for $\mathrm{b}^{*}, 0.7-2.4 \%$ for $\mathrm{L}^{*}, 1.9-8.3 \%$ for $\mathrm{HMF}$ and $0.1-5.7 \%$ for acrylamide. The baking process was considered reproducible since the RSD was lower than $10 \%$.

\section{Effect of chia flour on colour, texture, nutritional and antioxidant properties in biscuits}

Flours and biscuits were characterised for a number of physical and chemical parameters as summarised in Tables I and 2, respectively. Generally, the replacement of wheat flour by chia flour into the formulations significantly decreased the moisture content, water activity and $\mathrm{pH}$ of the biscuits as compared with the control sample $(p<0.05)$ (Table 2$)$. Colour of the flours was very different and, therefore, significant differences were observed in the biscuits, all the parameters decreasing when percentages of chia increased. Evolution of the colour could also be related to the browning associated with an advanced stage of Maillard reaction and caramelization (Morales \& Jiménez-Pérez, 200I) in samples with higher content of chia flour, as will be discussed later. Regarding the texture, the incorporation of chia flour did not have a significant effect on the hardness of the biscuits (Table 2), although lower values were obtained as compared with control.

As expected from the composition of the chia flour, its incorporation in the recipe increased the protein, fiber and lipid content, basically $\alpha$-linolenic acid, and decreased the carbohydrate content, showing significant differences when compared with the control sample (Table 2). The proportion of oleic acid and linoleic acid gradually decreased while that of a-linolenic acid increased (Table 3). However, taking into account that the lipid content increased with the chia addition (Table 2), the real PUFA content of the biscuits was greater than apparent as a percentage. Following the levels allowed by the European Commission (EC, 20/3), formulation B ( $10 \%$ chia) already could result in an enhanced product from a healthy and nutritional point of view. Similar results have also been demonstrated in other foods supplemented with chia seed, such as bread (Costantini et al., 2014) and chips (Coorey, Grant, \& Jayasena, 20I2).

Another positive factor of the incorporation of chia flour in the biscuits is associated with their antioxidant properties, basically derived from the presence of polyphenols in the chia seed (Costantini et al., 2014). Both wheat and chia flours and experimental biscuits were characterised according to their phenolic acids content (Tables I and 2). Biscuits enriched with chia resulted in greater contents of $p$-hydroxybenzoic acid, vanillic acid, p-coumaric acid, protocatechuic acid, caffeic acid and chlorogenic acid. These increases were significant for caffeic and chlorogenic acids from formulation $A$ ( $5 \%$ of chia), for p-hydroxybenzoic and protocatechuic acids from formulation B (10\% of chia) and for vanillic and p-coumaric when $15 \%$ chia was added. On the contrary, syringic acid did not show relevant differences probably due to the differences among the flours were not enough to exhibit modifications whereas ferulic acid significantly decreased in experimental formulations respect to the control. Overall, the total phenolic content significantly increased with the incorporation of chia, ranging from 134 to $377 \mathrm{mg}$ GAE/g sample in control sample and $20 \%$ chia added biscuit, respectively. In this respect, Costantini et al. (2014) also observed an increase in the total phenolic content when $10 \%$ of chia flour was added into the formulations of bread samples.

The antioxidant properties of chia-enriched biscuits were investigated through different assays: ABTS, DPPH, ORAC and FRAP (Table 2). Results showed a progressive and significant increase in the total antioxidant capacity of the biscuit with the replacement of wheat flour by chia flour in the recipe. Equivalent results have been reported in chips enriched with chia (Coorey et al., 2012). The antioxidant properties already known of the chia seed (Reyes-Caudillo et al., 2008) certainly contributed to that of the enrichedbiscuits. However the contribution of the Maillard reaction products (MRPs) cannot be discarded. Baking 
promotes the formation of MRPs, which have been demonstrated to show antioxidant properties (Horszwald et al., 20I0; Morales \& Jiménez-Pérez, 200I).

\section{Effect of chia flour on the formation of process contaminants in biscuits}

Changes in the content of process contaminants in the different formulations are presented in Fig. I. The results clearly show that the presence of chia has a strong influence on acrylamide, HMF and furfural formation in biscuits. Acrylamide levels ranged from $151 \mathrm{mg} / \mathrm{kg}$ (control) to $1187 \mathrm{mg} / \mathrm{kg}$ (formulation D) (Fig. Ia). Values in control samples are in line with the concentrations described in biscuits with similar formulations and treatments (Mesías et al., 2015a). Addition of $5 \%$ of chia significantly increased acrylamide formation but the highest levels were observed when 10\% of chia (permitted level) was incorporated (formulation B), even exceeding the indicative value established by the European Commission $(500 \mathrm{mg} / \mathrm{kg}$ ) (EC, 20II).

Similar results were found for the HMF and furfural content in the biscuits (Fig. Ib and c). Both compounds increased significantly with the incorporation of chia, reaching values of $71 \mathrm{mg} / \mathrm{kg}$ and $5.6 \mathrm{mg} / \mathrm{kg}$, respectively, in formulation $D$ ( $20 \%$ of chia). Similarly to acrylamide, the highest differences were observed when $10 \%$ of chia was added to the biscuits. Values of HMF were included within the range of 3.1 el $82.5 \mathrm{mg} / \mathrm{kg}$ displayed in commercial biscuits marketed in Spain (Delgado-Andrade, Rufi_an-Henares, \& Morales, 2009). For furfural, control biscuit exhibited a concentration close to that found in similar formulations but experimental recipes exceeded this value (Mesías et al., 2015a). As explained before, the higher antioxidant capacity in samples containing higher percentages of chia flour could be partly related to the higher formation of MRPs. Thereby, a significant correlation between the results of DPPH $(r=0.9763, p=0.0044)$, $\operatorname{ORAC}(r=0.8898, p=0.0432), \operatorname{FRAP}(r=0.9657, p=0.0076)$ and TPC $(r=0.9663, p=0.0074)$ with the furfural levels was observed and between DPPH and HMF $(r=0.8788, p=0.0497)$. No correlations were observed with the acrylamide values.

The higher formation of process contaminants in the samples could be related to the levels of precursors in the different formulations. In this regard, chia flour showed a lower content of reducing sugars but a higher one of free asparagine than those of wheat flour (Table I), leading to an asparagine/reducing sugars ratio of 4.2 for wheat flour versus 26.8 for chia flour. Asparagine has been defined as a key determinant for acrylamide formation in cereal/grain based products (FDE, 2013). Therefore it may explain the higher formation of acrylamide in the samples containing chia flour.

On the other hand, chia flour presented high levels of GO and MGO, whereas these compounds were not detected in wheat flour (Table I). Dicarbonyl compounds are reactive intermediates of the Maillard reaction and, in addition, can be formed by the degradation of sugars during caramelization and by lipid oxidation (Niyati-Shirkhodaee \& Shibamoto, 1993; Homoki-Farkas, Orsi, \& Kroh, 1997). The presence of dicarbonyl compounds in biscuits could be due to their formation as a consequence of thermal processing and besides to the content of both GO and MGO provided by the chia flour (Table I, Fig. 2). Previous studies have demonstrated that dicarbonyl compounds can be mainly responsible for the formation of the MRPs (EFSA, 2015). Thereby, MGO can be precursor of acrylamide formation in model systems (EFSA, 2015). Similarly, Arribas-Lorenzo et al. (2010) observed a relationship between acrylamide and HMF levels with MGO and GO content in cookies and an induction period was necessary to form process contaminants during the baking process. It may be suggested that during this period dicarbonyl compounds were formed up to an amount sufficient to generate MRPs. This fact could explain the results observed in the present experiments, where the progressive addition of the chia flour elevated the presence of dicarbonyl compounds, which

M. Mesías, F. Holgado, G. Márquez-Ruiz, F.J. Morales / LWT Food Science and Technology 73 (20I6) 528-535 pag. 7 
triggered the formation of the process contaminants. In agreement with Arribas-Lorenzo and Morales (2010), these findings confirm the important role of dicarbonyls in the formation of heat-induced contaminants in foods.

Phenolic compounds could also be involved in the generation of process contaminants, although contradictory information has been reported in the literature. Some authors have indicated that chlorogenic acid and ferulic acid promote acrylamide formation during heating (Bassama, Brat, Bohuon, Boulanger, \& Günata, 2010; Cai et al., 2014). However, the presence of total phenolic compounds and chlorogenic acid has also been negatively correlated with acrylamide formation in fried products (Kalita, Holm, \& Jayanty, 2013).

\section{Effect of chia flour on oxidative stability during storage of biscuits}

Biscuits were stored at $37^{\circ} \mathrm{C}$ in order to determine oxidative stability. Evaluation of the state of oxidation was analysed by the determination of primary oxidation products (measured by peroxide value) and, complementarily, by quantification of polymers (dimers and higher oligomers) as secondary oxidation compounds. Results for samples before storage and those obtained after 30 days-storage are presented in Table 4. Beyond one month, all samples except the control biscuits were too deteriorated to be analysed. Initially, no differences were observed in peroxide values and oxidation compounds between the different formulations, whereas a progressive increase of hydrolytic compounds, especially of free fatty acids, occurred with increasing addition of chia. Contribution of sunflower oil is discarded in this section since this oil is added to all the formulations in the same proportion. Therefore, these results are expected from the different content and composition of chia and wheat flour oils (Table I). Chia flour contains much higher amount of oil $(31 \%)$ than wheat flour $(1.8 \%)$ even though the content of hydrolytic compounds is lower in chia flour $(4.6 \%$ diacylglycerols and $8.4 \%$ free fatty acids in the extracted oil) than in wheat flour $(21 \%$ diacylglycerols and $16 \%$ free fatty acids in the extracted oil) (data not shown). After 30 days-storage, peroxide values and polymerization compounds increased remarkably, and values reached were higher as the percentage of chia in the formulations was greater. In fact, except for sample A, levels of polymerization compounds in biscuits added with chia were clearly unacceptable. Changes in the content of the main unsaturated fatty acids in oils extracted from the different formulations are shown in Fig. 3. Losses of unsaturated fatty acids were significant after one month in samples with over $5 \%$ of chia and, as expected, oxidation of a-linolenic acid was faster than that of linoleic and oleic acids. Higher losses were found in the formulations with higher amounts of chia flour, reaching reductions as relevant as $40 \%$ of linoleic and alinolenic acid in samples with $20 \%$ of chia. It is clear that the addition of chia flour greatly accelerated lipid oxidation. These findings are in agreement with those reported in the literature which have shown that the high content of a-linolenic acid makes chia oil less stable than other oils (Grompone, Irigaray, Rodríguez, \& Sammán, 2013) regardless of the substantial antioxidants content of chia (Reyes-Caudillo et al., 2008). Moreover, the contribution of other compounds with prooxidant effect in the chia flour should not be discarded. In summary, chia content in the formulation may condition the shelf-life of the biscuit. Nutritional benefits provided by the abundant PUFAs present in chia could be invalidated by the fast formation of advanced oxidation compounds.

\section{CONCLUSIONS}

The incorporation of chia flour into the formulation of wheat based biscuits resulted in a nutritionally enhanced product, with higher amount of protein, dietary fiber, antioxidants and mainly polyunsaturated fatty acids. However, the addition of chia flour significantly increased the formation of acrylamide, HMF and furfural and promoters such as methylglyoxal. Addition of $10 \%$ of chia flour (permitted level) even exceeded 
the indicative value for acrylamide in biscuits. Lipid oxidation was accelerated progressively in biscuits enriched with higher amounts of chia, thus decreasing the shelf-life of the products. Therefore, although nutritional properties of biscuits are improved by the incorporation of chia flour into the formulations, some side effects related to the formation of process contaminants after baking and the extent of the lipid oxidation during storage should be considered carefully in a context of risk/benefit when designing new chiabased biscuit formulations.

\section{DECLARATION OF INTEREST}

The authors declare that they have no conflict of interest.

\section{ACKNOWLEDGEMENTS}

This work was funded by projects SI0I3/ABI-3028-AVANSECAL (CAM) and CSIC-201370E027. Authors thank Harinas Polo for the supply of chia flour, Ms. I. Alvarez, Mr. MA. Martinez, Mr. G. Guerrero and Ms. M.J. Jiménez for their technical assistance with acrylamide, protein and texture determination.

\section{REFERENCES}

AACC. (2000). Approved methods of the American association of cereal Chemists. St Paul, Minnesota: Association of Cereal Chemists.

AOAC. (1999). Official method of analysis of AOAC Intl (16th ed.). Maryland: Association of Official Analytical Chemists.

Arribas-Lorenzo, G., \& Morales, F. J. (2010). Analysis, distribution, and dietary exposure of glyoxal and methylglyoxal in cookies and their relationship with other heat-induced contaminants. Journal of Agricultural and Food Chemistry, 58, 2966-2972.

Bassama, J., Brat, P., Bohuon, P., Boulanger, R., \& Günata, Z. (2010). Study of acrylamide mitigation in model system: Effect of pure phenolic compounds. Food Chemistry, 123, 558-562.

Cai, Y., Zhang, Z., Jiang, S., Yu, M., Huang, C., Qiu, R., et al. (2014). Chlorogenic acid increased acrylamide formation through promotion of HMF formation and 3-aminopropionamide deamination. Journal of Hazardous Materials, 268, I-5.

Coorey, R., Grant, A., \& Jayasena, V. (2012). Effects of Chia flour incorporation on the nutritive quality and consumer acceptance of chips. Journal of Food Research, I, 85-95.

Costantini, L., Luk_sic, L., Molinari, R., Kreft, I., Bonafaccia, G., Manzi, L., et al. (2014). Development of gluten-free bread using tartary buckwheat and chia flour rich in omega-3 fatty acids and flavonoids as ingredients. Food Chemistry, 165, 232-240.

Delgado-Andrade, C., Rufi_an-Henares, J. A., \& Morales, F. J. (2009). Hydroxymethylfurfural in commercial biscuits marketed in Spain. Journal of Food and Nutrition Research, 48, 14-19.

Dubois, M., Gilles, K. A., Hamilton, J. K., Rebers, P. A., \& Smith, F. (1956). Colorimetric method for determination of sugars and related substances. Analytical Chemistry, 28, 350-356.

EC (European Commission). (20II). Commission recommendation of $10.1 .201 \mathrm{I}$ on investigations into the levels of acrylamide in food. http://ec.europa.eu/food/food/ chemicalsafety/contaminants/recommendation_100I20II_acrylamide_food_en.pdf Accessed 10.10.15.

EC (European Commission). (2013). Commission implementing decision of 22.1.2013 authorising an extension of use of Chia (Salvia hispanica) seed as a novel food ingredient under Regulation (EC) No 258/97 of the European Parliament and of the Council. OJEU. L 2I/34-35.

EFSA. (2005). Opinion of the Scientific Panel on food additives, flavourings, processing aids and materials in contact with food (AFC) related to Flavouring Group Evaluation 13 (FGE.I3); Furfuryl and furan derivatives 
with and without additional sidechain substituents and heteroatoms from chemical group 14. http://www.efsa.europa.eu/en/scdocs/scdoc/215.htm Accessed 16.10.15.

EFSA. (2015). Scientific opinion on acrylamide in food. EFSA Journal, 13, 4104. http://www.efsa.europa.eu/sites/default/files/scientific_output/files/main_documents/4I04.pdf Accessed 10.10.15.

FDE. (2013). Food drink Europe. Acrylamide toolbox. http://www.fooddrinkeurope. eu/uploads/publications_documents/AcrylamideToolbox_2013.pdf Accessed 02.10.15.

García-Martínez, M. C., Rodríguez-Alcal_a, L. M., Marmesat, S., Alonso, L., Fontecha, J., \& M_arquez-Ruiz, G. (2010). Lipid stability in powdered infant formula stored at ambient temperatures. International Journal of Food Science and Technology, 45, 2337-2344.

G€okmen, V., Serpen, A., \& Fogliano, V. (2009). Direct measurement of the total antioxidant capacity of foods: The 'QUENCHER' approach. Trends in Food Science and Technology, 20, 278-288.

Grompone, M. A., Irigaray, B., Rodríguez, D., \& Samm_an, N. (2013). Assessing the oxidative stability of commercial chia oil. Journal of Food Science and Engineering, 3, 349-356.

Høie, A. H., Svendsen, C., Brunborg, G., Glatt, H., Alexander, J., Meinl,W., et al. (2015). Genotoxicity of three food processing contaminants in transgenic mice expressing human sulfotransferases IAI and IA2 as assessed by the in vivo alkaline single cell gel electrophoresis assay. Environmental and Molecular Mutagenesis, 56, 709-7I4.

Homoki-Farkas, P., Orsi, F., \& Kroh, L. W. (1997). Methylglyoxal determination from different carbohydrates during heat processing. Food Chemistry, 59, 157-163.

Horszwald, A., Morales, F. J., del Castillo, M. D., \& Zielinski, H. (2010). Evaluation of antioxidant capacity and formation of processing contaminants during rye bread making. Journal of Food and Nutrition Research, 49, 149-159.

IUPAC. (1992a). Method 2.30I. In A. Dieffenbacher, \& W. D. Pocklington (Eds.), Standard methods for the analysis of oils, fats and derivatives. Oxford, UK: Blackwell Scientific.

IUPAC. (1992b). Method 2.302. In A. Dieffenbacher, \& W. D. Pocklington (Eds.), Standard methods for the analysis of oils, fats and derivatives. Oxford, UK: Blackwell Scientific.

IUPAC. (1992c). Method 2.50I. In A. Dieffenbacher, \& W. D. Pocklington (Eds.), Standard methods for the analysis of oils, fats and derivatives. Oxford, UK: Blackwell Scientific.

Kalita, D., Holm, D. G., \& Jayanty, S. S. (20I3). Role of polyphenols in acrylamide formation in the fried products of potato tubers with colored flesh. Food Research International, 54, 753-759.

Lee, S. C., Prosky, L., \& De Vries, J. W. (1992). Determination of total, soluble and insoluble dietary fíber in foods. EnzymaticeGravimetric method, MES-TRIS buffer: Collaborative study. Journal of AOAC International, 75, 395-416.

M_arquez-Ruiz, G., \& Dobarganes, M. C. (2007). High-performance size-exclusion chromatography for lipid analysis in organic media. In J. K. G. Kramer, R. E. McDonald, J. T. Brenna, \& M. M. Mossoba (Eds.), Lipid analysis and lipidomics. New techniques and applications (pp. 205e238). Champaign, IL, USA: AOCS Press.

Martínez-Villaluenga, C., Gulewicz, P., Frias, J., Gulewicz, K., \& Vidal-Valverde, C. (2008). Assessment of protein fractions of three cultivars of Pisum sativum L.: Effect of germination. European Food Research Technology, 226, I465-I478.

Mesías, M., Holgado, F., Márquez-Ruiz, G., \& Morales, F. J. (2015a). Effect of sodium replacement in cookies on the formation of process contaminants and lipid oxidation. LWT Food Science and Technology, 62, 633639.

Mesías, M., Holgado, F., Sevenich, R., Brian, J. C., Márquez-Ruiz, G., \& Morales, F. J. (20I5b). Fatty acids profile in canned tuna and sardine after retort sterilization and high pressure thermal sterilization treatment. Journal of Food and Nutrition Research, 54, I7I-178. 
Mesías, M., Navarro, M., Gökmen, V., \& Morales, F. J. (20l3). Antiglycative effect of fruit and vegetable seed extracts: Inhibition of age formation and carbonyl trapping abilities. Journal of the Science of Food and Agricultural, 93, 2037-2044.

Miller, G. L. (1959). Use of dinitrosalicylic acid reagent for determination of reducing sugars. Analytical Chemistry, 31, 426-428.

Morales, F. J. (2008). Hydroxymethylfurfural (HMF) and related compounds. In R. H. Stadler, \& D. R. Lineback (Eds.), Process-induced food toxicants: Occurrence, formation, mitigation, and health risks (pp. 135e 174). Hoboken, NJ, USA: John Wiley \& Sons, Inc.

Morales, F. J., \& Jiménez-Pérez, S. (200I). Free radical scavenging capacity of Maillard reaction products as related to colour and fluorescence. Food Chemistry, 72, I19-125.

Morales, F. J., Martin, S., Açar, O. C., Arribas-Lorenzo, G., \& Gökmen, V. (2009). Antioxidant activity of cookies and its relationship with heat-processing contaminants: A risk/benefit approach. European Food Research Technology, 228, 345-354.

Niva, M. (2007). 'All foods affect health': Understandings of functional foods and healthy eating among health-oriented Finns. Appetite, 48, 384-393.

Niyati-Shirkhodaee, F., \& Shibamoto, T. (1993). Gas-chromatographic analysis of glyoxal and methylglyoxal formed from lipids and related-compounds upon ultraviolet-irradiation. Journal of Agricultural and Food Chemistry, 4I, 227-230.

Prosky, L., Asp, N. G., Schweizer, T. F., Devries, J.W., \& Furda, I. (1992). Determination of insoluble and soluble dietary fiber in foods and food products; collaborative study. Journal of AOAC International, 75, 360-367.

Reyes-Caudillo, E., Tecante, A., \& Valdivia-López, M. A. (2008). Dietary fibre content and antioxidant activity of phenolic compounds present in Mexican chia (Salvia hispanica L.) seeds. Food Chemistry, 107, 656-663. Zamora, R., \& Hidalgo, F. J. (20I I). The Maillard reaction and lipid oxidation. Lipid Technology, 23, 59-62. 
FIGURES AND TABLES

Table I. Characterization of wheat flour and chia flour.

\begin{tabular}{|c|c|c|}
\hline & Wheat flour & Chia flour \\
\hline Moisture (\%) & $8.6 \pm 0.1 b$ & $4.4 \pm 0.0 \mathrm{a}$ \\
\hline Water activity & $0.34 \pm 0.0 \mathrm{a}$ & $0.35 \pm 0.0 \mathrm{a}$ \\
\hline $\mathrm{pH}$ & $6.5 \pm 0.0 \mathrm{a}$ & $6.7 \pm 0.0 b$ \\
\hline $\mathrm{a}$ & $0.3 \pm 0.0 \mathrm{a}$ & $2.7 \pm 0.1 b$ \\
\hline b & $8.7 \pm 0.1 \mathrm{a}$ & $9.4 \pm 0.1 b$ \\
\hline L & $48.1 \pm 0.7 a$ & $87.4 \pm 0.4 b$ \\
\hline E Index & $87.9 \pm 0.5 b$ & $49.1 \pm 0.8 a$ \\
\hline Water retention capacity (\%) & $1 \mathrm{I} .1 \pm 0.3 \mathrm{a}$ & $99.7 \pm 0.3 b$ \\
\hline Proteins $(\mathrm{g} / \mathrm{l} 00 \mathrm{~g})$ & $10.4 \pm 0.1 \mathrm{a}$ & $19.8 \pm 0.1 b$ \\
\hline Lipids (g/l00 g) & $1.9 \pm 0.2 \mathrm{a}$ & $3 \mathrm{l} .1 \pm 0.3 \mathrm{~b}$ \\
\hline Carbohydrates $(\mathrm{g} / \mathrm{I} 00 \mathrm{~g})^{*}$ & $85.0 \pm 1.2 b$ & $33.6 \pm 0.6 \mathrm{a}$ \\
\hline Total dietary fiber $(\mathrm{g} / \mathrm{l} 00 \mathrm{~g})$ & $3.4 \pm 0.4 a$ & $30.9 \pm 1.3 b$ \\
\hline Reducing sugars $(\mathrm{g} / \mathrm{l} 00 \mathrm{~g})$ & $5.6 \pm 0.0 b$ & $1.6 \pm 0.0 \mathrm{a}$ \\
\hline Free asparagine $(\mathrm{mg} / \mathrm{l} 00 \mathrm{~g})$ & $23.4 \pm 1.1 \mathrm{a}$ & $42.8 \pm 1.2 b$ \\
\hline \multicolumn{3}{|l|}{ Phenolic acids ( $\mu g / g)$} \\
\hline p-hydroxybenzoic acid & $\mathrm{I} . \mathrm{I} \pm 0.0 \mathrm{a}$ & $4.9 \pm 0.1 b$ \\
\hline syringic acid & $\mathrm{I} .3 \pm 0 . \mathrm{Ib}$ & $0.1 \pm 0.0 \mathrm{a}$ \\
\hline vanillic acid & $0.3 \pm 0.0 \mathrm{a}$ & $8.7 \pm 0.4 b$ \\
\hline p-coumaric acid & $2.7 \pm 0.2 \mathrm{a}$ & $10.3 \pm 0.0 \mathrm{~b}$ \\
\hline caffeic acid & $\mathrm{I} .5 \pm 0 . \mathrm{la}$ & $356.8 \pm 1.5 b$ \\
\hline ferulic acid & $56.4 \pm 2.2 b$ & $35.7 \pm 0.4 a$ \\
\hline protocatechuic acid & $\mathrm{I} .2 \pm 0 . \mathrm{Ia}$ & $14.9 \pm 0.7 b$ \\
\hline chlorogenic acid & $<\mathrm{LOQ}$ & $36.0 \pm 0.8$ \\
\hline $\mathrm{HMF}(\mathrm{mg} / \mathrm{kg})$ & $<\mathrm{LOQ}$ & $<\mathrm{LOQ}$ \\
\hline Furfural (mg/kg) & $<\mathrm{LOQ}$ & $<$ LOQ \\
\hline Acrylamide $(\mu \mathrm{g} / \mathrm{kg})$ & $<\mathrm{LOQ}$ & $<\mathrm{LOQ}$ \\
\hline MGO $(\mu g / g)$ & $<$ LOQ & $371 \pm 82$ \\
\hline $\mathrm{GO}(\mu \mathrm{g} / \mathrm{g})$ & $<\mathrm{LOQ}$ & $3.0 \pm 0.1$ \\
\hline
\end{tabular}

*Carbohydrates include total dietary fiber, starch and sugars. HMF: hydroxymethylfurfural. MGO: methylglyoxal. GO: glyoxal. LOQ: Limit of quantification. Results are mean \pm standard deviation. Different letters in the same row mean significant differences $(p<0.05)$ 
Table 2. Characterization of biscuits with different chia flour content.

\begin{tabular}{|c|c|c|c|c|c|}
\hline & Control & $\mathrm{A}$ & B & $\mathrm{C}$ & $\mathrm{D}$ \\
\hline Moisture (\%) & $3.6 \pm 0.2 b$ & $1.9 \pm 0.1 \mathrm{a}$ & $2.0 \pm 0.1 \mathrm{a}$ & $1.7 \pm 0.1 \mathrm{a}$ & $1.7 \pm 0.1 \mathrm{a}$ \\
\hline Water activity & $0.19 \pm 0.00 b$ & $0.19 \pm 0.00 b$ & $0.10 \pm 0.0 \mathrm{la}$ & $0.11 \pm 0.00 \mathrm{a}$ & $0.11 \pm 0.00 \mathrm{a}$ \\
\hline $\mathrm{pH}$ & $8.3 \pm 0.0 d$ & $7.6 \pm 0.0 c$ & $7.5 \pm 0.0 b$ & $7.4 \pm 0.0 \mathrm{a}$ & $7.3 \pm 0.1 \mathrm{a}$ \\
\hline $\mathrm{a}$ & $6.5 \pm 0.2 b c$ & $7.2 \pm 0.4 d$ & $6.2 \pm 0.4 \mathrm{ab}$ & $6.6 \pm 0.2 c$ & $5.9 \pm 0.2 a$ \\
\hline$b$ & $23.0 \pm 0.5 e$ & $19.9 \pm 0.4 \mathrm{~d}$ & $18.7 \pm 0.6 c$ & $16.6 \pm 0.6 b$ & $14.6 \pm 0.4 a$ \\
\hline $\mathrm{L}$ & $68.5 \pm 0.5 \mathrm{e}$ & $57.7 \pm 0.6 \mathrm{~d}$ & $56.2 \pm 0.8 c$ & $51.3 \pm 1.0 \mathrm{~b}$ & $49.4 \pm 0.6 a$ \\
\hline$E$ index & $72.6 \pm 0.6 e$ & $61.4 \pm 0.7 d$ & $59.5 \pm 0.9 c$ & $54.3 \pm 1.2 b$ & $51.8 \pm 0.6 a$ \\
\hline Hardness (N) & $123.2 \pm 0.4 b$ & $85.1 \pm 2.3 a$ & $84.2 \pm 11.2 \mathrm{a}$ & $108.3 \pm 7.8 \mathrm{~b}$ & $113.6 \pm 15.5 \mathrm{ab}$ \\
\hline Proteins (g/l00 g) & $8.8 \pm 0.1 \mathrm{a}$ & $9.7 \pm 0.0 b$ & $10.3 \pm 0.0 c$ & $11.0 \pm 0.0 \mathrm{~d}$ & $11.7 \pm 0.0 \mathrm{e}$ \\
\hline Lipids (g/l00 g) & $13.7 \pm 0.3 \mathrm{a}$ & $15.5 \pm 0.1 b$ & $17.1 \pm 0.2 c$ & $19.4 \pm 0.3 d$ & $21.1 \pm 0.1 \mathrm{e}$ \\
\hline Carbohydrates $(\mathrm{g} / 100 \mathrm{~g})^{*}$ & $75.9 \pm 0.9 d$ & $68.5 \pm 0.9 c$ & $65.9 \pm 1.6 b$ & $59.9 \pm 0.7 a$ & $59.0 \pm 1.5 a$ \\
\hline Total dietary fiber $(\mathrm{g} / \mathrm{l} 00 \mathrm{~g})$ & $5.1 \pm 0.4 \mathrm{a}$ & $9.5 \pm 1.3 \mathrm{~b}$ & $12.5 \pm 0.6 c$ & $16.8 \pm 0.5 d$ & $20.7 \pm 1.8 \mathrm{e}$ \\
\hline \multicolumn{6}{|l|}{ Phenolic acids ( $\mu g / g)$} \\
\hline p-hydroxybenzoic acid & $1.0 \pm 0.0 \mathrm{a}$ & $\mathrm{I} . \mathrm{I} \pm 0 . \mathrm{Ia}$ & $1.3 \pm 0.0 \mathrm{~b}$ & $1.4 \pm 0.1 \mathrm{c}$ & $1.6 \pm 0.1 d$ \\
\hline syringic acid & $1.3 \pm 0.1 \mathrm{c}$ & $1.2 \pm 0.1 \mathrm{bc}$ & $\mathrm{I} . \mathrm{I} \pm 0 . \mathrm{Ib}$ & $0.9 \pm 0.0 \mathrm{a}$ & $\mathrm{I} . \mathrm{I} \pm 0 . \mathrm{Ib}$ \\
\hline vanillic acid & $0.4 \pm 0.0 \mathrm{a}$ & $0.6 \pm 0.1 \mathrm{a}$ & $0.5 \pm 0.2 \mathrm{a}$ & $\mathrm{I} . \mathrm{I} \pm 0.2 \mathrm{~b}$ & $2.9 \pm 0.1 c$ \\
\hline p-coumaric acid & $3.0 \pm 0.2 \mathrm{a}$ & $3.1 \pm 0.2 \mathrm{a}$ & $3.4 \pm 0.1 \mathrm{ab}$ & $3.9 \pm 0.1 b$ & $4.3 \pm 0.1 c$ \\
\hline caffeic acid & $1.4 \pm 0.0 \mathrm{a}$ & $24.2 \pm 0.8 b$ & $46.8 \pm 0.8 c$ & $67.3 \pm 2.1 d$ & $93.3 \pm 0.4 \mathrm{e}$ \\
\hline ferulic acid & $62.6 \pm 1.4 \mathrm{~d}$ & $56.3 \pm 4.7 c d$ & $52.2 \pm 2.2 b c$ & $49.4 \pm 0.8 a b$ & $46.7 \pm 1.9 a$ \\
\hline protocatechuic acid & $0.7 \pm 0.0 \mathrm{a}$ & $0.6 \pm 0.0 \mathrm{a}$ & $1.5 \pm 0.2 \mathrm{~b}$ & $\mathrm{I} .8 \pm 0 . \mathrm{Ib}$ & $2.3 \pm 0.3 c$ \\
\hline chlorogenic acid & $0.5 \pm 0.0 \mathrm{a}$ & $\mathrm{I} .8 \pm 0 . \mathrm{Ib}$ & $2.7 \pm 0.2 c$ & $4.5 \pm 0.4 d$ & $9.1 \pm 0.2 \mathrm{e}$ \\
\hline TPC ( $\mu g$ GAE/g) & $134 \pm 4 a$ & $219 \pm 14 b$ & $250 \pm 8 c$ & $348 \pm 10 d$ & $377 \pm 6 e$ \\
\hline ABTS $(\mu \mathrm{mol}$ TEAC/g) & $11.0 \pm 0.3 a$ & $13.2 \pm 0.1 b$ & $13.5 \pm 0.3 b c$ & $15.1 \pm 0.1 d$ & $14.0 \pm 0.2 c$ \\
\hline DPPH $(\mu \mathrm{mol}$ TEAC/g) & $8.3 \pm 0.8 a$ & $9.7 \pm 0.8 \mathrm{ab}$ & $10.3 \pm 0.2 \mathrm{ab}$ & $10.7 \pm 1.4 b$ & $11.8 \pm 1.4 b$ \\
\hline ORAC ( $\mu \mathrm{mol}$ TEAC/g) & $56.0 \pm 3.4 a$ & $73.6 \pm 0.9 b$ & $96.9 \pm 13.3 c$ & $106.6 \pm 3.2 c$ & $119.5 \pm 4.8 \mathrm{~d}$ \\
\hline FRAP $(\mu \mathrm{mol}$ TEAC/g) & $4.8 \pm 0.0 \mathrm{a}$ & $7.5 \pm 0.0 b$ & $8.5 \pm 0.1 c$ & $11.0 \pm 0.3 d$ & $13.2 \pm 0.2 \mathrm{e}$ \\
\hline
\end{tabular}

Control: $0 \%$ chia flour. A: $5 \%$ chia flour. B: 10\% chia flour. C: 15\% chia flour. D: $20 \%$ chia flour. Results are mean \pm standard deviation. Different letters in the same row mean significant differences $(p<0.05)$

*Carbohydrates include total dietary fiber, starch and sugars. 
Table 3. Fatty acid methyl ester (FAME) composition (relative percentages) of lipids extracted from wheat flour, chia flour and biscuits with different chia flour content.

\begin{tabular}{|c|c|c|c|c|c|c|c|c|}
\hline \multirow[b]{2}{*}{ FAME } & \multirow[b]{2}{*}{ Sunflower oil } & \multicolumn{2}{|c|}{ Flours } & \multicolumn{5}{|c|}{ Biscuits } \\
\hline & & Wheat & Chia & Control & A & B & C & $\mathrm{D}$ \\
\hline $\mathrm{Cl} 4: 0$ & $0.1 \pm 0.0$ & $0.1 \pm 0.0 \mathrm{~A}$ & $0.1 \pm 0.0 \mathrm{~A}$ & $0.1 \pm 0.0 \mathrm{a}$ & $0.1 \pm 0.0 \mathrm{a}$ & $0.1 \pm 0.0 \mathrm{a}$ & $0.1 \pm 0.0 \mathrm{a}$ & $0.1 \pm 0.0 \mathrm{~b}$ \\
\hline $\mathrm{Cl} 6: 0$ & $6.5 \pm 0.1$ & $16.0 \pm 0.1 \mathrm{~B}$ & $6.9 \pm 0.1 \mathrm{~A}$ & $6.7 \pm 0.1 \mathrm{a}$ & $6.7 \pm 0.0 \mathrm{a}$ & $6.6 \pm 0.0 \mathrm{a}$ & $6.6 \pm 0.0 \mathrm{a}$ & $6.6 \pm 0.0 \mathrm{a}$ \\
\hline Cl6:I & $0.2 \pm 0.1$ & $0.2 \pm 0.0 \mathrm{~A}$ & $0.1 \pm 0.0 \mathrm{~A}$ & $0.1 \pm 0.0 \mathrm{a}$ & $0.1 \pm 0.0 b$ & $0.1 \pm 0.0 b$ & $0.1 \pm 0.0 c$ & $0.1 \pm 0.0 c$ \\
\hline $\mathrm{Cl} 8: 0$ & $3.5 \pm 0.1$ & $1.3 \pm 0.0 \mathrm{~A}$ & $3.5 \pm 0.0 \mathrm{~B}$ & $3.4 \pm 0.0 \mathrm{a}$ & $3.4 \pm 0.0 \mathrm{a}$ & $3.4 \pm 0.0 b$ & $3.5 \pm 0.0 b$ & $3.5 \pm 0.0 c$ \\
\hline Cl8:I & $25.9 \pm 0.2$ & $16.6 \pm 0.0 \mathrm{~B}$ & $7.3 \pm 0.0 \mathrm{~A}$ & $30.9 \pm 0.1 \mathrm{e}$ & $28.5 \pm 0.1 d$ & $26.6 \pm 0.0 c$ & $24.9 \pm 0.0 b$ & $23.6 \pm 0.1 \mathrm{a}$ \\
\hline $\mathrm{Cl} 8: 2$ & $61.8 \pm 0.7$ & $60.9 \pm 0.1 \mathrm{~B}$ & $18.5 \pm 0.0 \mathrm{~A}$ & $56.9 \pm 0.1 \mathrm{e}$ & $53.0 \pm 0.1 d$ & $50.1 \pm 0.0 c$ & $47.1 \pm 0.1 b$ & $45.0 \pm 0.1 \mathrm{a}$ \\
\hline $\mathrm{Cl} 8: 3$ & n.d. & $3.9 \pm 0.2 \mathrm{~A}$ & $63.4 \pm 0.1 \mathrm{~B}$ & $0.2 \pm 0.0 \mathrm{e}$ & $6.7 \pm 0.1 d$ & $11.6 \pm 0.1 \mathrm{c}$ & $16.6 \pm 0.1 \mathrm{~b}$ & $19.8 \pm 0.2 \mathrm{a}$ \\
\hline C20:0 & $0.2 \pm 0.0$ & $0.2 \pm 0.0 \mathrm{~A}$ & $0.3 \pm 0.0 \mathrm{~A}$ & $0.3 \pm 0.0 c$ & $0.3 \pm 0.0 c$ & $0.3 \pm 0.0 b$ & $0.3 \pm 0.0 b$ & $0.3 \pm 0.0 \mathrm{a}$ \\
\hline C22:0 & $0.6 \pm 0.1$ & n.d. & n.d. & $0.6 \pm 0.1 \mathrm{c}$ & $0.6 \pm 0.0 \mathrm{bc}$ & $0.5 \pm 0.0 \mathrm{bc}$ & $0.5 \pm 0.0 \mathrm{ab}$ & $0.5 \pm 0.0 \mathrm{a}$ \\
\hline
\end{tabular}

Control: $0 \%$ chia flour. A: $5 \%$ chia flour. B: $10 \%$ chia flour. C: $15 \%$ chia flour. D: $20 \%$ chia flour.

Results are mean \pm standard deviation. Different letters in the same row mean significant differences among the samples $(p<0.05)$. Capital letters are referred to the significant differences among the flours and lowercase letters to those among biscuits. n.d. - not detected. 
Table 4. Polymerization compounds (dimers and higher oligomers), hydrolytic compounds (diglycerides and free fatty acids) and peroxide values in extracted oils from biscuits with different chia flour content at initial time and after I month of storage.

\begin{tabular}{|c|c|c|c|c|c|}
\hline & Control & A & $B$ & $\mathrm{C}$ & $\mathrm{D}$ \\
\hline \multicolumn{6}{|c|}{ Dimers (wt\% on oil) } \\
\hline Initial & $1.4 \pm 0.1 \mathrm{Aa}$ & $1.3 \pm 0.1 \mathrm{Aa}$ & $1.3 \pm 0.1 \mathrm{Aa}$ & $1.3 \pm 0.1 \mathrm{Aa}$ & $\mathrm{I} . \mathrm{I} \pm 0 . \mathrm{IAa}$ \\
\hline I month & $1.9 \pm 0.1 \mathrm{Aa}$ & $3.0 \pm 0.3 \mathrm{Bb}$ & $6.9 \pm 0.3 \mathrm{Bc}$ & $14.0 \pm 0.8 \mathrm{Bd}$ & $18.5 \pm 0.6 \mathrm{Be}$ \\
\hline \multicolumn{6}{|c|}{ Higher oligomers (wt\% on oil) } \\
\hline Initial & n.d. & n.d. & n.d. & n.d & n.d. \\
\hline I month & n.d. & $0.9 \pm 0.1 \mathrm{a}$ & $4.0 \pm 0.7 b$ & $14.6 \pm 2.0 c$ & $35.3 \pm 3.8 d$ \\
\hline \multicolumn{6}{|c|}{ Diglycerides (wt\% on oil) } \\
\hline Initial & $2.3 \pm 0.3 \mathrm{Aa}$ & $2.6 \pm 0.3 \mathrm{Aa}$ & $2.9 \pm 0.4 \mathrm{Aab}$ & $2.9 \pm 0.3 \mathrm{Ab}$ & $3.0 \pm 0.3 \mathrm{Ab}$ \\
\hline I month & $2.5 \pm 0.4 \mathrm{Aa}$ & $2.5 \pm 0.3 \mathrm{Aa}$ & $2.7 \pm 0.3 \mathrm{Aa}$ & $2.5 \pm 0.4 \mathrm{Aa}$ & $2.6 \pm 0.3 \mathrm{Aa}$ \\
\hline \multicolumn{6}{|c|}{ Free fatty acids (wt\% on oil) } \\
\hline Initial & $0.4 \pm 0.1 \mathrm{Aa}$ & $0.8 \pm 0.1 \mathrm{Ab}$ & $1.4 \pm 0.1 \mathrm{Ac}$ & $1.7 \pm 0.3 \mathrm{Acd}$ & $2.2 \pm 0.1 \mathrm{Ad}$ \\
\hline I month & $0.5 \pm 0.1 \mathrm{Aa}$ & $0.6 \pm 0.1 \mathrm{Aa}$ & $1.4 \pm 0.1 \mathrm{Ab}$ & $2.2 \pm 0.4 \mathrm{Ac}$ & $3.7 \pm 0.3 \mathrm{Bd}$ \\
\hline \multicolumn{6}{|c|}{ Peroxide value (meq $\mathrm{O}_{2} / \mathrm{kg}$ oil) } \\
\hline Initial & $25 \pm 2.7 \mathrm{Aa}$ & $30 \pm 2.9 \mathrm{Aa}$ & $23 \pm 4.8 \mathrm{Aa}$ & $30 \pm 1.6 \mathrm{Aa}$ & $26 \pm 3.6 \mathrm{Aa}$ \\
\hline I month & $150 \pm 17 \mathrm{Ba}$ & $917 \pm 126 \mathrm{Bb}$ & $1221 \pm 102 \mathrm{Bc}$ & $2860 \pm 151 \mathrm{IBd}$ & $2404 \pm 139 B d$ \\
\hline
\end{tabular}

wt\%: weight percentage. Control: $0 \%$ chia flour. A: $5 \%$ chia flour. B: $10 \%$ chia flour. C: $15 \%$ chia flour. D: $20 \%$ chia flour. Results are mean \pm standard deviation. Capital letters are referred to the significant differences among samples initially and after I month of storage. Lowercase letters are referred to the significant differences among the different formulations $(p<0.05)$. n.d. - not detected. 
Figure I. Acrylamide (mg/kg) (a), HMF (mg/kg) (b) and furfural $(\mathrm{mg} / \mathrm{kg})$ (c) concentrations in biscuits as influenced by the addition of different percentages of chia flour. Control: $0 \%$ chia flour. A: $5 \%$ chia flour. B: $10 \%$ chia flour. C: $15 \%$ chia flour. D: $20 \%$ chia flour. Results are expressed in fresh matter. Values are mean \pm standard deviation. Different letters mean significant differences $(p<0.05)$.
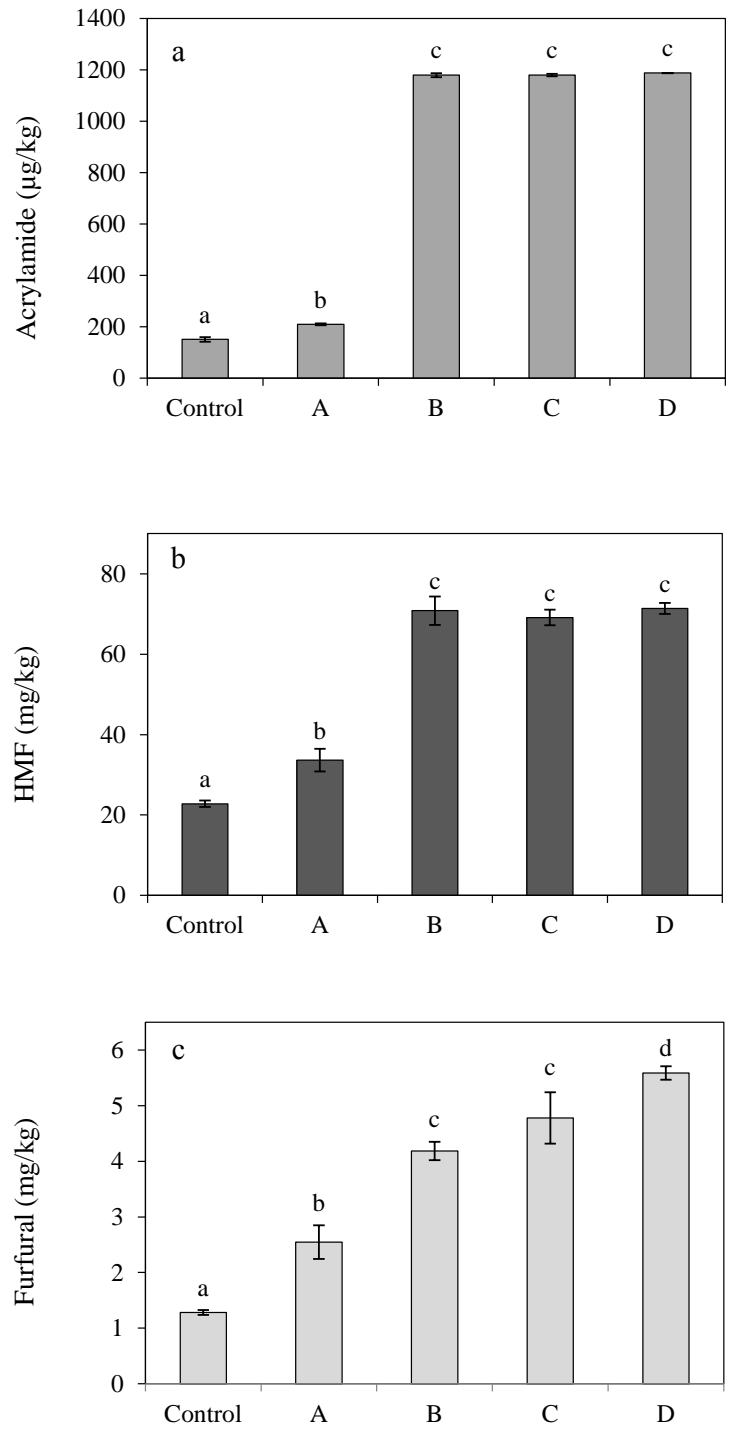

Biscuit models 
Figure 2. Methylglyoxal (MGO) (a) and glyoxal (GO) (b) concentrations ( $\mathrm{mg} / \mathrm{kg}$ ) in biscuits as influenced by the addition of different percentages of chia flour. Control: $0 \%$ chia flour. A: $5 \%$ chia flour. B: $10 \%$ chia flour. C: $15 \%$ chia flour. D: $20 \%$ chia flour. Results are expressed in fresh matter. Values are mean \pm standard deviation. Different letters mean significant differences $(p<0.05)$.
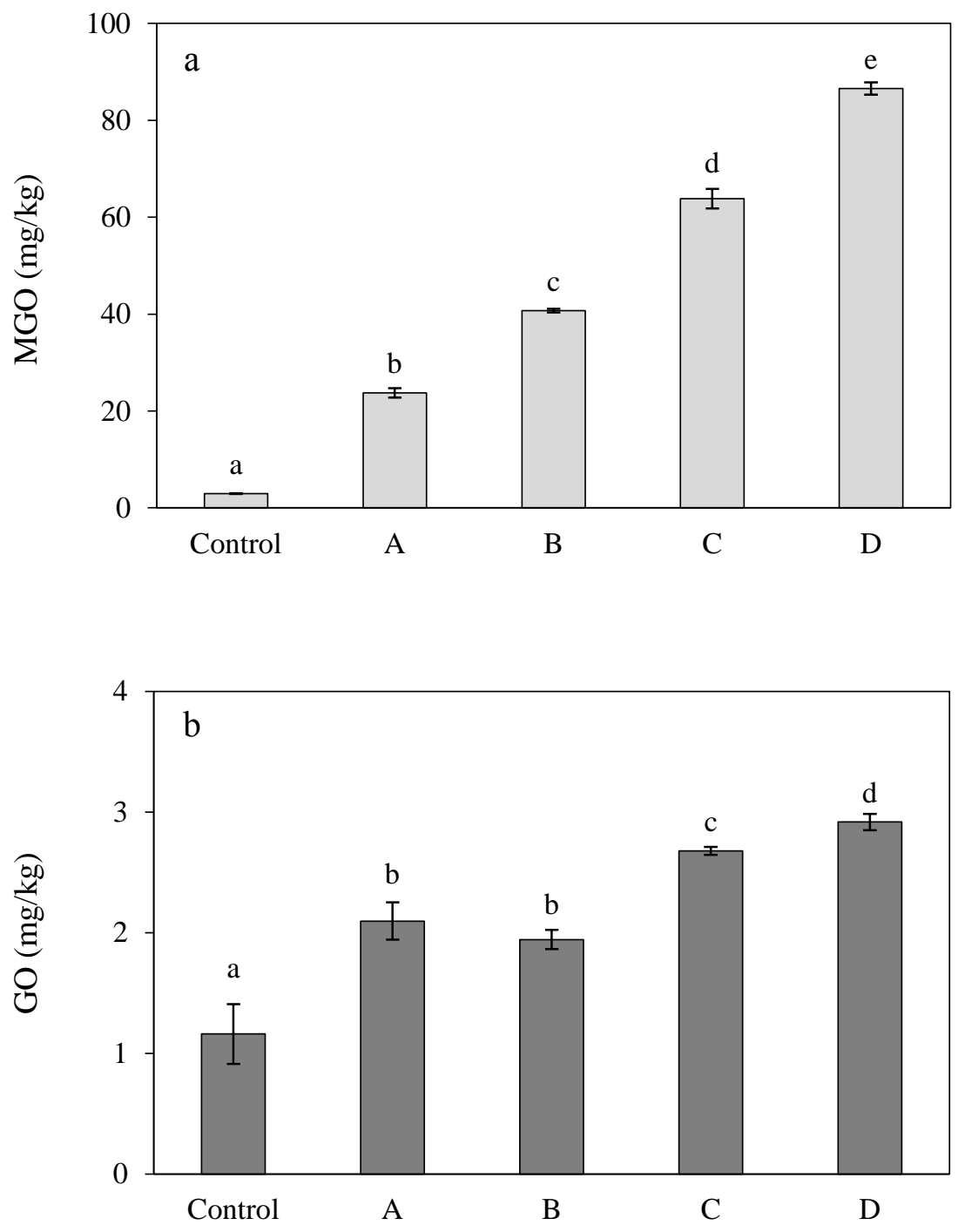

Biscuit models 
Figure 3. Changes in main unsaturated fatty acid methyl esters (FAME) in lipids extracted from biscuits initially (black bars) and after one month-storage (gray bars) as influenced by the addition of different percentages of chia flour. Control: $0 \%$ chia flour. A: $5 \%$ chia flour. B: $10 \%$ chia flour. C: $15 \%$ chia flour. D: $20 \%$ chia flour. Values are mean \pm standard deviation. Different letters mean significant differences $(p<$ 0.05).

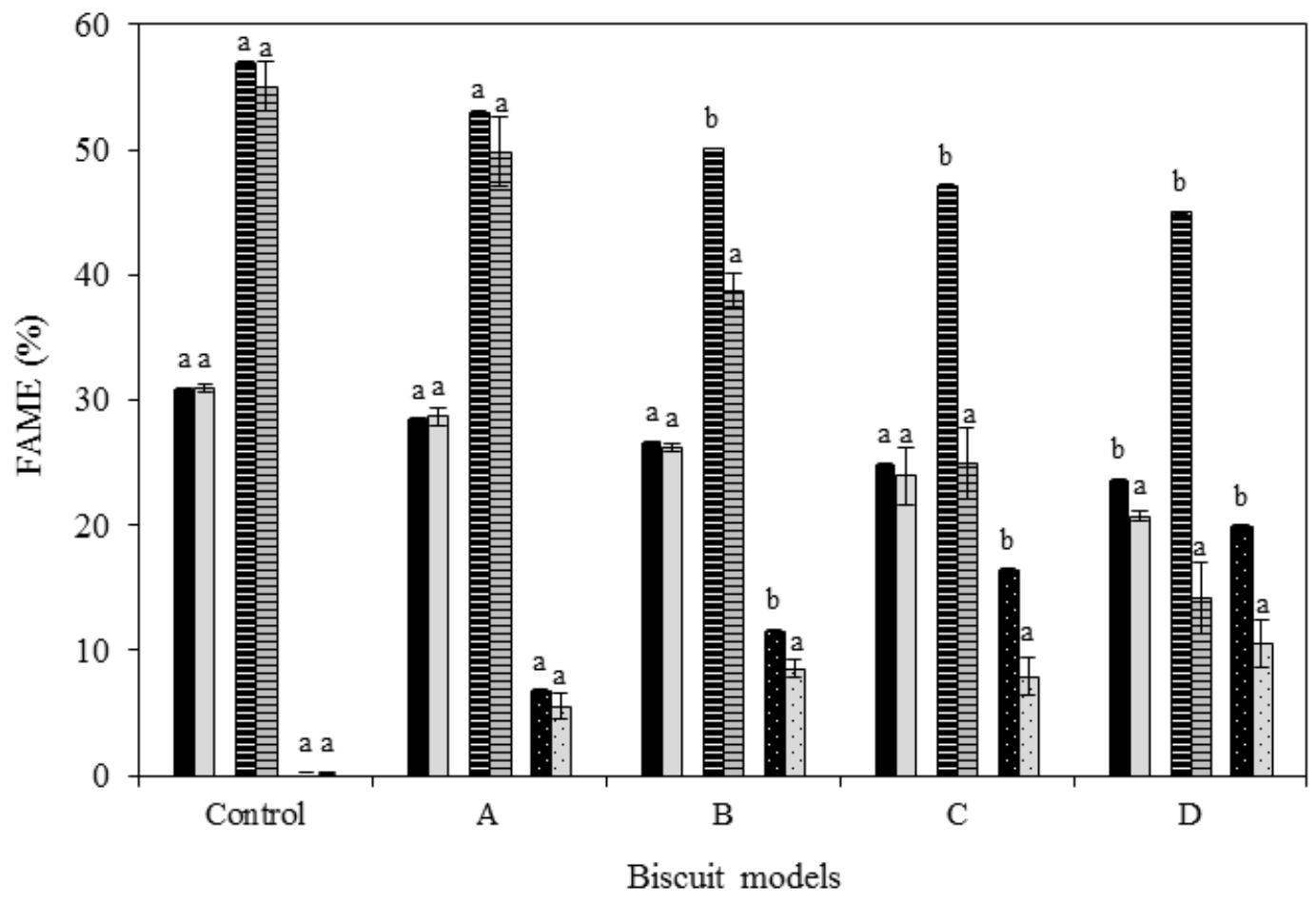

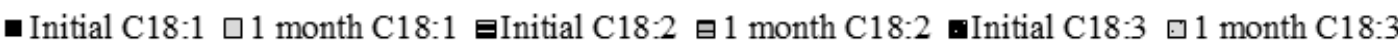

